\title{
Effect of oestradiol valerate on the rat blood-testis and blood-epididymal barriers to $\left[{ }^{3} \mathrm{H}\right]$ inulin
}

\author{
T. T. Turner, R. D. Giles and S. S. Howards \\ Departments of Urology and Physiology, University of Virginia School of Medicine, \\ Charlottesville, Virginia 22908, U.S.A.
}

\begin{abstract}
Summary. Micropuncture samples were taken from rats treated with $2.9 \mathrm{mg}$ oestradiol valerate/day for 14 days, sham injected or untreated. Oestradiol valerate treatment reduced testicular weight and serum testosterone concentrations $(P<0.05)$, but did not alter the movement of $\left[{ }^{3} \mathrm{H}\right]$ inulin into seminiferous tubules or those of the cauda epididymidis. $\left[{ }^{3} \mathrm{H}\right]$ Inulin concentrations in the seminiferous tubule fluids were always $<8 \%$ of blood isotope concentrations, and those in cauda epididymidal tubule fluid were always $<5 \%$ of blood isotope concentrations. It was concluded that the maintenance of the anatomical component of the blood-testis and blood-epididymal barriers (cell-cell tight junctions) is not androgen-dependent.
\end{abstract}

\section{Introduction}

The blood-testis and blood-epididymal barriers limit the ability of blood-borne macromolecules to enter the lumen of tubules of the male reproductive tract (Setchell, Voglmayr \& Waites, 1969; Howards, Jessee \& Johnson, 1976). The structural component of the blood-testis barrier is highly impermeable to electron-opaque tracers such as lanthanum (Neaves, 1973), an impermeability that is resistent to degradation by vasectomy (Neaves, 1973), artificial cryptorchidism (Hagenäs, Plöen, Ritzén \& Ekwall, 1977), short-term efferent duct ligation (Osman \& Plöen, 1978), or treatment with anti-androgens (Vitale, Fawcett \& Dym, 1973). In-vivo micropuncture studies have allowed examinations of the blood-testis barrier and blood-epididymal barrier (Howards et al., 1976) which are perhaps more sensitive than the lanthanum exclusion studies. These studies have shown small changes in the $\left[{ }^{3} \mathrm{H}\right]$ inulin penetrability of these barriers in hamsters after vasectomy (Turner, D'Addario \& Howards, 1979) and in rats after artificial cryptorchidism (Turner, D'Addario, Forrest \& Howards, 1981).

The testis and epididymis are androgen-dependent organs. To determine whether maintenance of the blood-testis and blood-epididymal barriers are part of this androgen dependency in the adult rat we have examined their permeability to $\left[{ }^{3} \mathrm{H}\right]$ inulin after oestrogen treatment.

\section{Materials and Methods}

Adult male Sprague-Dawley rats $(450-550 \mathrm{~g})$ were obtained from university vivarium sources and acclimatized for at least 1 week before experimental use. At the time of the micropuncture experiments, animals were anaesthetized with urethane $(1 \mathrm{mg} / \mathrm{kg})$, nephrectomized, and prepared for conventional micropuncture (Howards, Johnson \& Jessee, 1975). Carotid arterial and jugular 
venous cannulae were inserted for blood sampling and isotope infusion, respectively. $\left[{ }^{3} \mathrm{H}\right.$ ] Inulin (sp. act. $380 \mathrm{mCi} / \mathrm{g}$; New England Nuclear, Boston, Massachusetts) was infused $(1 \mu \mathrm{Ci}$ in $1 \mathrm{ml}$ $0.154 \mathrm{M}-\mathrm{NaCl}$ ) via the jugular cannula over a 5 -min period. Beginning $20 \mathrm{~min}$ after the completion of the infusion and continuing at 20-min intervals thereafter for a total of $140 \mathrm{~min}$, blood samples were taken from the carotid cannula and micropuncture samples of the luminal contents were obtained from the seminiferous tubules and the cauda epididymidis.

After collection of the microsamples (spermatozoa + fluid), cell-free fluids were obtained by centrifuging the samples at $3600 \mathrm{~g}$ for $15 \mathrm{~min}$ in a refrigerated $\left(0^{\circ} \mathrm{C}\right)$ centrifuge. Cell-free fluids were placed under water-equilibrated mineral oil. Duplicate or, when possible, triplicate $100 \mathrm{nl}$ samples of each fluid were transferred via a calibrated volumetric micropipette into a mini-scintillation vial containing $3 \mathrm{ml}$ scintillation fluid. Radioactivity in the samples was measured in a scintillation spectrophotometer (Beckman 7000). Testicular weights of each animal in each group were obtained. At the end of the micropuncture procedure, blood samples were taken from sham- and oestradiol-treated animals for testosterone analysis.

Blood samples were analysed for testosterone by conventional radioimmunoassay using commercially available kits (New England Nuclear, Boston, Massachusetts). Testosterone was extracted with anhydrous diethyl ether, dried under an air stream, resuspended in isooctane :benzene:methanol (90:5:5 by vol.), and chromatographed on precalibrated LH-20 columns. Recovery of known standards averaged $70 \%$. The sensitivity of the assay was 5 $\mathrm{pg} /$ assay tube. The intra- and inter-assay variability were 4 and $7 \%$, respectively. Values for water blanks and charcoal-extracted serum blanks were less than $0.5 \mathrm{ng} / \mathrm{ml}$.

\section{Treatment protocol}

Control animals received no treatment before use in the micropuncture experiments. The treated animals received $0.5 \mathrm{ml}$ injections of oestradiol valerate $(20 \mathrm{mg} / \mathrm{ml}$ in castor oil-benzylbenzoate, $80: 20 \mathrm{v} / \mathrm{v}$ ) on Days $0,4,8$ and 12 of treatment. Micropuncture samples were taken on Day 14. At the time of the experiments therefore, the animals had received a dose of $2.9 \mathrm{mg}$ oestradiol valerate/day for 14 days. Sham-treated animals received $0.5 \mathrm{ml}$ injections of castor oil-benzylbenzoate solution $(80: 20, \mathrm{v} / \mathrm{v})$ according to the same injection schedule as the treatment animals.

\section{Data analysis}

Counts per minute (c.p.m.) per unit volume of tubule fluid were divided by the c.p.m. per unit volume of blood plasma collected at the same time period. This quotient multiplied by 100 equals the percentage of blood plasma isotope concentrations that appeared in the luminal fluids at each collection time. Within each group of animals, the mean amount of $\left[{ }^{3} \mathrm{H}\right]$ inulin entering the seminiferous and epididymal tubules was calculated for each time. The permeability data and testis weights from each group of animals were compared by analysis of variance. Serum testosterone concentrations were compared by Student's $t$ test. A $P$ value of 0.05 or less was considered significant.

\section{Results}

The testes of oestradiol-treated rats weighed (mean \pm s.e.m.) significantly less $(0.98 \pm 0.03 \mathrm{~g})$ than did those of control animals $(1.85 \pm 0.05 \mathrm{~g})$ or sham-injected animals $(1.54 \pm 0.06 \mathrm{~g})$. In those animals treated with oestradiol valerate for 2 weeks, serum testosterone concentrations $(1.49 \pm 0.15 \mathrm{ng} / \mathrm{ml})$ were significantly reduced relative to those of the sham-injected animals $(4.28 \pm 0.48 \mathrm{ng} / \mathrm{ml})$. 
In all the groups, $\left[{ }^{3} \mathrm{H}\right]$ inulin concentrations in the cauda epididymidis were significantly less than in the seminiferous tubules (Text-fig. 1). In control animals, $\left[{ }^{3} \mathrm{H}\right]$ inulin concentrations in the seminiferous tubule fluids reached an apparent plateau at approximately $5 \%$ of blood plasma concentrations (Text-fig. 1). In the epididymides of controls, the plateau was reached at approximately $1 \%$ of blood plasma concentrations.

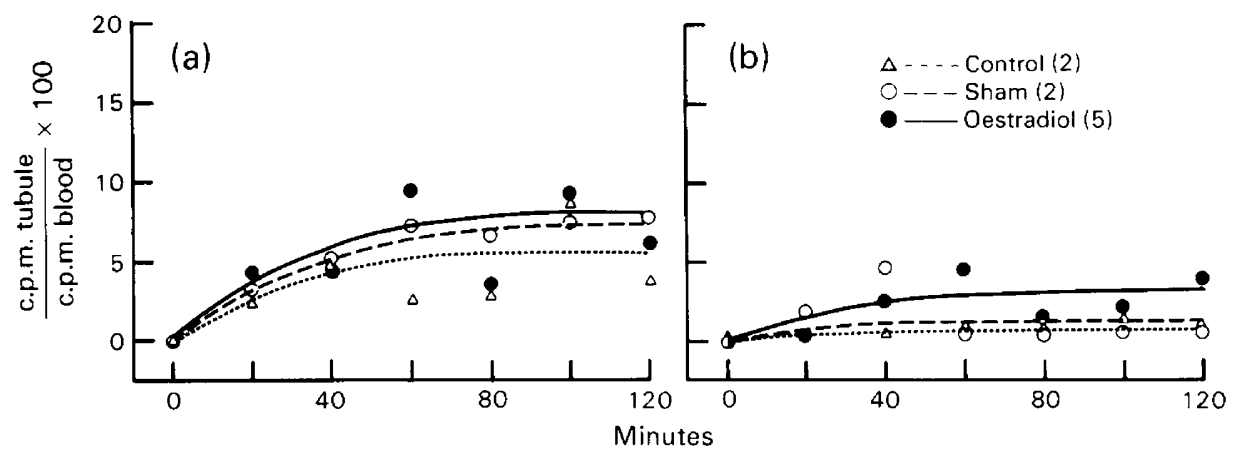

Text-fig. 1. The relative amounts of $\left[{ }^{3} \mathrm{H}\right]$ inulin in the blood plasma and (a) seminiferous tubule and (b) epididymal tubule (cauda) of rats left untreated, injected with oil or injected with oestradiol for 14 days. The number of animals is indicated in parentheses. The regression lines for each group are constructed from the equation $y=a b^{x}$, for which each data group had an $r^{2}>$ 0.9 .

In the oestradiol-treated rats, $\left[{ }^{3} \mathrm{H}\right]$ inulin concentrations in the seminiferous tubules reached a plateau at approximately $7-8 \%$ of blood plasma concentration and the value for the cauda epididymidis was $3-4 \%$. Neither oestradiol treatment nor sham injection caused a significant difference in $\left[{ }^{3} \mathrm{H}\right]$ inulin concentrations in the luminal fluids of the seminiferous tubule or the cauda epididymidis.

\section{Discussion}

The data on testis weights and serum testosterone concentrations demonstrated the antiandrogenic effect of the oestradiol treatment. In the control rats there was only limited entry of $\left[{ }^{3} \mathrm{H}\right.$ linulin into the seminiferous tubule lumen and practically no entry into the epididymal lumen. These data are similar to those obtained by Turner et al. (1979) using the hamster and are consistent with the results of Cooper \& Waites (1979) from rat epididymal perfusion studies. Inulin (mol. wt $=5000$ ) is an inert molecule which enters the tubule lumen by passive diffusion; it is therefore a marker for the 'tightness' of the cell-cell tight junctions which form the structural component of the blood-tissue barrier.

Oestradiol and sham treatment were associated with a tendency towards higher intraluminal $\left[{ }^{3} \mathrm{H}\right.$ linulin concentrations, but these differences were not statistically significant. This was probably due to the large individual variation, particularly in the oestradiol-treated animals. This variance can be attributed to the difficulty of obtaining good micropuncture samples from the atrophic testes and epididymides of oestradiol-treated animals. This problem was unavoidable since oestradiol treatment reduced testicular size considerably and effectively collapsed the epididymis. Nevertheless, this treatment clearly did not allow $\left[{ }^{3} \mathrm{H}\right]$ inulin to pass freely through the structural blood-testis and blood-epididymis barriers. It remains possible that anti-androgen treatment does cause a slight increased leakiness in these barriers and that a small but real increase was not statistically detected by our study.

Vitale et al. (1973) showed that oestradiol treatment did not prevent the establishment of the 
Sertoli cell-Sertoli cell tight junctions in pubertal rats. The present results have demonstrated that maintenance of the established blood-testis and blood-epididymis barrier is not an androgendependent process in adult animals.

We thank Dr C. S. Singhas for the testosterone measurements. This work was supported by NIH grant HD90490.

\section{References}

Cooper, T.G. \& Waites, G.M.H. (1979) Investigation by luminal perfusion of the transfer of compounds into the epididymis of the anaesthetized rat. J. Reprod. Fert. 56, 159-164.

Hagenäs, L., Plöen, L., Ritzén, E. M. \& Ekwall, H. (1977) Blood-testis barrier: maintained function of the inter-sertoli cell junctions in experimental cryptorchidism in the rat, as judged by a simple lanthanum-immersion technique. Andrologia.9, $250-254$.

Howards, S.S., Johnson, A.L. \& Jessee, S.J. (1975) Micropuncture and microanalytic studies of the rat testis and epididymis. Fert. Steril. 26, 13-19.

Howards, S.S., Jessee, S.J. \& Johnson, A.L. (1976) Micropuncture studies of the blood-seminiferous tubule barrier. Biol. Reprod. 14, 264-269.

Neaves, W.B. (1973) Permeability of sertoli cell tight junctions to lanthanum after ligation of ductus deferens and ductuli efferentes. J. Cell Biol. 59, $559-572$.
Osman, D. I. \& Plöen, L. (1978) The terminal segment of the seminiferous tubules and the blood-testis barrier before and after efferent ductule ligation in the rat. Int. J. Androl. 1, 235-249.

Setchell, B. P., Voglmayr, J. K. \& Waites, G.M.H. (1969) A blood-testis barrier restricting passage from blood into the rete testis fluid but not in lymph. J. Physiol., Lond. 200, 73-85.

Turner, T.T., D'Addario, D.A. \& Howards, S.S. (1979) Effects of vasectomy on the blood-testis barrier of the hamster. J. Reprod. Fert. 55, 323-328.

Turner, T.T., D'Addario, D.A., Forrest, J.B. \& Howards, S.S. (1981) The effects of experimental cryptorchidism on the entry of $\left[{ }^{3} \mathrm{H}\right]$-inulin and $\left[{ }^{3} \mathrm{H}\right]$-horseradish peroxidase into the lumen of the rat seminiferous tubule. $J$. Androl. (in press).

Vitale, R., Fawcett, D.W. \& Dym, M. (1973) The normal development of the blood-testis barrier and the effects of clomiphene and estrogen treatment. Anat. Rec. 176, 333-344. 